\title{
Nutrition and the Immune System: A Complicated Tango
}

\author{
Carina Venter ${ }^{1, *}$, Stefanie Eyerich ${ }^{2}{ }^{\mathbb{D}}$, Tara Sarin ${ }^{1}$ and Kevin C. Klatt ${ }^{3}$ \\ 1 Section of Allergy \& Immunology, School of Medicine, University of Colorado Denver, \\ Children's Hospital Colorado, Anschutz Medical Campus, 13123 East 16th Avenue, Aurora, CO 80045, USA; \\ Tara.Sarin@childrenscolorado.org \\ 2 Center of Allergy and Environment (ZAUM), Technical University and Helmholtz Center Munich, \\ Biedersteinerstrass 29, 80802 Munich, Germany; stefanie.eyerich@tum.de \\ 3 USDA/ARS Children's Nutrition Research Center, Baylor College of Medicine, Houston, TX 77030, USA; \\ kcklattphd@gmail.com \\ * Correspondence: Carina.Venter@childrenscolorado.org; Tel.: +1-720-777-6844
}

Received: 10 February 2020; Accepted: 13 March 2020; Published: 19 March 2020

\begin{abstract}
Enthusiasm exists for the potential of diet to impact the immune system, prevent disease and its therapeutic potential. Herein, we describe the challenge to nutrition scientists in defining this relationship through case studies of diets and nutrients in the context of allergic and autoimmune diseases. Moderate-quality evidence exists from both human intervention and observational studies to suggest that diet and individual nutrients can influence systemic markers of immune function and inflammation; numerous challenges exist for demonstrating the impact of defined diets and nutrient interventions on clearly influencing immune-mediated-clinical disease endpoints. A growing body of evidence suggests that further consideration of dietary patterns, immune system and gut microbiome composition and function, and subsequent epigenetic modifications are needed to improve our understanding of diet-immune system interactions.
\end{abstract}

Keywords: nutrition; omega-3 fatty acids; fiber; immune system; microbiome

\section{Introduction}

The complexity of the interaction between nutrition and immunology is vast. An individual's overall nutrition status, state of nourishment, and pattern of food intake (comprised of foods, nutrients and non-nutritive bioactive compounds) impact the functioning of the immune system; this impact can occur at the level of physical barriers (e.g., skin, intestinal mucous membranes), the microbiome, the innate immune system (e.g., macrophage function and polarization) and the adaptive immune system (e.g., T- and B-cell function). Conversely, the immune system impacts nutrition metabolism and needs, and influences the physiological response to food. This complex relationship between nutrition, diet and the immune system underlies the rationale behind this current review. Within, we will describe the developing field of nutritional immunology through case studies of the relationship between nutrition and the immune system.

\section{Approaches to Studying Nutrition and the Immune System}

Assessing the bidirectional relationship between diet and the immune system can be undertaken utilizing multiple approaches. In human intervention studies, investigators have assessed the impact of bioenergetic status [1], isolated nutrients [2-6], and dietary patterns, such as the Mediterranean Diet $[7,8]$, in both controlled feeding and free-living intervention studies on numerous indices of immune function (e.g., circulating cytokines, high-sensitivity C-reactive Protein, antibodies, tissue-specific 
transcriptomes). To complement such intervention approaches, a growing body of literature, utilizing observational study designs, has assessed dietary intakes via self-reported measures and circulating biomarkers, and assessed their associations with similar immune function outputs, as well as disease endpoints (e.g., allergy incidence, chronic disease risk). Such investigations have occurred in a variety of populations, including pregnant women and young infants, adults, individuals with chronic disease, metabolic syndrome, allergic, inflammatory and/or autoimmune diseases. Typically, these clinical observations follow and are complemented by investigations in laboratory animals and cultured cells to provide mechanistic insights, although important differences in immune system development and function $[9,10]$ and lack of in vivo interactions limit the direct translation of findings in animal studies to humans.

It is critical to note that, at present, few large, randomized controlled trials exist with clinical endpoints (e.g., event reduction; disease remission) that demonstrate an impact of diet on immune-mediated disease risk. In some instances, such as the case of early dairy protein exposure and risk of beta-cell autoimmunity, bioplausible hypotheses have not been confirmed in large clinical trials [11]. The difficulties facing nutritional immunology and the caveats of relying on surrogate endpoints are made further evident by the long history of testing the inflammation-atherosclerosis hypothesis; researchers have spent decades employing numerous anti-inflammatory agents prior to demonstrating an effect of interleukin (IL)-1 beta inhibition on cardiovascular event risk reduction. While enthusiasm for nutrition and immune-mediated disease risk abounds, careful consideration of the nature and quality of the data are paramount.

\section{Nutrition and Immune-Mediated Disease Risk}

Dietary intake throughout the life span ranging from conception to old age, has been hypothesized to play a significant role in the development, management and treatment of noncommunicable diseases including allergic diseases, cancer, diabetes, and cardiovascular disease. Notably, such noncommunicable diseases have well-described immunopathological processes, raising the possibility that immunomodulatory aspects of diet may causally influence disease risk and management. The incidence of immune-mediated diseases is elevated in Westernized countries where the burden of such diseases is high, typically ascribed to common dietary components such as the high intakes of total calories, fat and added sugars, low intakes of fiber, and imbalanced fatty acid composition of the diet. Consistent with these ecological correlations, specific nutrients and dietary patterns have been associated with lower risk of allergic and chronic inflammatory disease development [12,13]. A growing body of preclinical and clinical literature has emerged describing the impact of individual dietary components and dietary patterns on markers of immune function, potentially underlying some of these associations (Table 1). A thorough description of the field of nutritional immunology is beyond the scope of a single review; thus, to highlight specific ways that researchers have studied this relationship, below we describe both allergic and autoimmune diseases and the possible impact of nutrition on disease incidence and management. 
Table 1. Impact of diet patterns/types (A), nutrients (B) other nutritional factors (C) and food preparation/production (D) on gut barrier function, inflammation and the microbiome.

\begin{tabular}{|c|c|c|}
\hline \multicolumn{3}{|c|}{ (A) Diet Patterns/Types } \\
\hline Gut Barrier Function & Inflammation & Microbiome \\
\hline & & $\begin{array}{l}\text { Overall diet can affect production of inflammatory/anti-inflammatory metabolites } \\
\text { by microbiome [14] } \\
\begin{array}{l}\text { A "tolerant" gut microbiome may reduce expression of IL-33 and TSLP and may } \\
\text { protect against sensitization to food allergens [15]. } \\
\text { (mainly murine models) }\end{array}\end{array}$ \\
\hline $\begin{array}{l}\text { Western type diet: high saturated/trans fat and protein; } \\
\text { low fiber: may affect goblet cell function and reduce } \\
\text { mucus layer [16] in murine models }\end{array}$ & & $\begin{array}{c}\text { Western-type diet: high saturated/trans fat and protein; low fiber: Can lead to low } \\
\text { microbial diversity. } \\
\text { Reduces populations in the phylum Bacteroidetes and increases Firmicutes and } \\
\text { Proteobacteria in murine models } \\
\text { Reduces populations in the phylum Bacteroidetes and increases Firmicutes and } \\
\text { Proteobacteria in human studies [17-20] }\end{array}$ \\
\hline & & $\begin{array}{l}\text { Higher diet diversity is associated with a more diverse gut microbiome in human } \\
\text { studies. Diet diversity has been reported to prevent allergic disease [21], but it's } \\
\text { direct role in the management of food allergy has not been investigated [22-24] } \\
\text { High levels of butyrate and proprioate and a diet high in fermented foods, fruit and } \\
\text { vegetables and fish infancy is also associated with reduced allergy outcomes [25]. }\end{array}$ \\
\hline \multicolumn{3}{|c|}{ (B) Nutrients } \\
\hline Gut Barrier Function & Inflammation & Microbiome \\
\hline & $\begin{array}{l}\text { Vitamins-particularly Vitamin A and B9, affect T-regulatory cell } \\
\text { function and act as ligands }[26,27] \text { as demonstrated in murine models. }\end{array}$ & \\
\hline $\begin{array}{l}\text { Omega-6 fatty acids: enhance tight junctions [28] } \\
\text { in murine models }\end{array}$ & $\begin{array}{l}\text { Long chain poly-unsaturated fatty acids particularly omega-3 fatty } \\
\text { acids: suppress allergic inflammation via its effect on resolvin D1 } \\
\text { and peroxisome proliferator-activated receptors (PPAR) in } \\
\text { murine models [29] } \\
\text { Can also affect the FADS1 genotype (rs174550) [18,19] }\end{array}$ & \\
\hline $\begin{array}{l}\text { Acid; Docosahexaenoic Acid } \\
\text { (long chain omega } 3 \text { fatty acids) [30,31] }\end{array}$ & hsCRP, IL-6, TNF-alpha $[30,31]$ & \\
\hline Dietary Sodium [32-35] & Increased Th-17/T-regulatory ratio & \\
\hline \multirow[t]{2}{*}{ Dietary Genistein and Daidzein (soy isoflavones) [36] } & Decreased CRP & \\
\hline & $\begin{array}{l}\text { Amino acids: play and important role in cell wall structures } \\
\text { in murine models [37] }\end{array}$ & $\begin{array}{l}\text { Amino acids: Certain amino acids such as D-tryptophan may affect the production } \\
\text { of bacterial products that can positively affect immune mediated diseases } \\
\text { as shown in murine [37]. }\end{array}$ \\
\hline
\end{tabular}


Table 1. Cont

\begin{tabular}{|c|c|c|}
\hline \multicolumn{3}{|c|}{ (C) Other Nutritional Factors } \\
\hline Gut Barrier Function & Inflammation & Microbiome \\
\hline $\begin{array}{l}\text { Advanced glycosylated end products (AGEs): may } \\
\text { affect epithelial cell function as shown in murine } \\
\text { models }[38,39]\end{array}$ & $\begin{array}{l}\text { AGEs may affect inflammatory processes, particularly via its effect on } \\
\text { IL-33 and TSLP as shown in mice [40] }\end{array}$ & $\begin{array}{l}\text { AGEs: may negatively affect the microbiome composition as shown in a rodent } \\
\text { model [41]. }\end{array}$ \\
\hline \multicolumn{3}{|c|}{$\begin{array}{l}\text { AGE content of foods may be affected by sugar content, grilling or roasting meats, high fat content, highly processed foods, fruit juices [42], high fructose corn syrup [43,44] and fizzy drinks [45]. Steaming, boiling, } \\
\text { slow-cooking and using acids when cooking can reduce the amounts of AGEs produced [40]. }\end{array}$} \\
\hline & & $\begin{array}{l}\text { Prebiotics: selectively stimulate the growth of beneficial bacteria and might offer } \\
\text { protection against effects of AGEs as shown in a human trial [46] }\end{array}$ \\
\hline \multirow[t]{2}{*}{$\begin{array}{l}\text { Fiber: Short chain fatty acids (SCFAs) are produced } \\
\text { through the fermentation of polysaccharides and } \\
\text { improve gut barrier function via its effect on IL-22 } \\
\text { (promoting mucus production) as shown in murine } \\
\text { models }[47,48]\end{array}$} & $\begin{array}{l}\text { Fiber: Short chain fatty acids (SCFAs) are produced through the } \\
\text { fermentation of polysaccharides and reduce allergic inflammation as } \\
\text { shown in murine models }[47,48]\end{array}$ & \\
\hline & & Polyphenols: Increase gut microbial diversity $[49,50]$ indicated by human studies \\
\hline $\begin{array}{l}\text { Emulsifiers e.g., polysorbate } 80 \text { and } \\
\text { carboxymethylcellulose may destroy the epithelial } \\
\text { mucous layer in the gut as shown in mice [51] }\end{array}$ & $\begin{array}{l}\text { Emulsifiers e.g., polysorbate } 80 \text { and carboxymethylcellulose, promote } \\
\text { inflammation as shown in mice [51] }\end{array}$ & $\begin{array}{l}\text { Emulsifiers e.g., polysorbate } 80 \text { and carboxymethylcellulose, alter gut microbial } \\
\text { composition as shown in mice [51] }\end{array}$ \\
\hline \multicolumn{3}{|c|}{ (D) Food Preparation/Production } \\
\hline \multirow[t]{3}{*}{ Gut Barrier Function } & Inflammatory Processes & Microbiome \\
\hline & & $\begin{array}{l}\text { Uncooked foods, cooking methods and processing can affect the natural microbial } \\
\text { load of foods-Fresh foods contain their own microbiome, including nonpathogenic } \\
\text { bacteria (e.g., Lactobacillus plantarum on fruits and vegetables) [52,53] }\end{array}$ \\
\hline & & $\begin{array}{l}\text { Phthalates (a chemical compound from packaging) found in fast foods [54] and } \\
\text { some initial data from murine models indicate that it may reduce microbioal } \\
\text { diversity in the gut [55] }\end{array}$ \\
\hline
\end{tabular}

lymphopoietin; SCFAs: short-chain fatty acids. Bold indicates the particular nutrient factor studied. 


\section{Allergic Disease}

Allergy is an immune-mediated reaction, specific to an encounter with a range of allergens such as foods or environmental exposures [56]. It can present in almost every organ and launch a range of symptoms such as anaphylaxis, urticaria, angioedema, allergic rhinoconjunctivitis, allergic asthma, allergic vasculitis and atopic dermatitis (eczema) [57]. The four most common allergic diseases are referred to as eczema, food allergy, asthma and rhinitis [58]. Eczema and food allergies usually develop in infancy, and affected infants often progress onward, developing asthma and allergic rhinitis in a sequential manner called the 'allergic march' [59]. The immunological processes underpinning allergic diseases presents in two phases-the sensitization phase and the effector phase. During the sensitization phase, naïve $T$ cells recognize an allergen and differentiate into $\mathrm{T}$ helper (Th) 2 effector cells that secrete IL-4, IL-5 and IL-13 that, in turn, induce allergen specific immunoglobulin (Ig) E production by B-cells [60]. Allergen-specific IgE binds to the high-affinity receptor (Fc\&RI) on mast cells and basophils completing the sensitization phase. When the immune system encounters the allergen again the effector phase is induced. Here, the allergen binds to surface-bound IgE and cross-links two FceRI receptors on mast cells or basophils leading to consecutive release of pre-formed mediators such as histamine and prostaglandin that provoke the typical allergic symptoms described above. Whereas T-, B-, mast cells, eosinophils and basophils represent essential cellular mediators during sensitization and effector inflammation, a defective epithelial barrier has been more recently shown to allow penetration of allergens, bacterial toxins and other particles, leading to inflammation and release of IL-25, IL-31, IL-33 and thymic stromal lymphopoietin (TSLP) [61] that stimulate the production of allergen-specific IgE, the recruitment of eosinophils and other inflammatory cells, mucous production and reduce contraction of smooth muscles [59]. Thereby, allergic reactions are induced by a complex interaction of cells and mediators of both, innate and adaptive immunity.

\section{Overall Diet}

The best evidence that overall nutritional intake may play a role in allergy prevention comes from the studies focusing on diet diversity in infancy. The European Academy of Allergy and Clinical Immunology (EAACI) position paper [62] regarding diet diversity and prevention of allergies concludes that diet diversity in infancy may be associated with reduced allergy outcomes in childhood and may be beneficial given low to no risk of harm [62]. Diet diversity is defined as the number of different foods or food groups over a reference period, and should ideally include frequency of consumption and the health value of the food. It is thought that diet diversity may influence allergy outcomes via its effect on the microbiome and immune system. This alteration in the immune system may be mediated through a multitude of immune antigen tolerance mechanisms including $\mathrm{T}$ and $\mathrm{B}$ regulatory cells, immune regulatory cytokines and suppressed $\operatorname{IgE}$ antibodies as demonstrated in other allergen tolerance models [62]. So far, all studies into diet diversity have been conducted in infancy [21,62]. A recent study indicates that both increased diet diversity and allergen diversity in the first year of life, is associated with a reduced risk of developing food allergy over the first ten years of life [21]. No studies focusing on diet diversity during the other life stages such as pregnancy and later life and allergy outcomes have been published.

Data on other diet patterns, in particular, the Mediterranean diet, give some evidence that eating according to these diet patterns in pregnancy may reduce wheeze or eczema in the infant. No study focusing on diet patterns in infancy, and other life stages on allergy outcomes have been conducted [62].

\section{Single Nutrients}

\subsection{Omega-3 and Omega-6}

Responses to immune stimuli require both the initiation and resolution of an immune response [63]. Central to this coordinated response are polyunsaturated fatty acids (PUFAs) of the omega- 6 and omega-3 series that serve as substrates for the synthesis of signaling molecules, including eicosanoids 
and docosanoids (Figure 1) [64]. Diet serves as a source of a variety of key PUFAs, including the essential fatty acids, linoleic acid $(18,2 n-6)$ and alpha-linolenic acid $(18,3 n-3)$, as well as their longer chain and more highly unsaturated products arachidonic acid (arachidonic acids (AA); 20, 4n-6), eicosapentaenoic acid (eicosapentanoic acid (EPA; 20, 5n-3)) and docosahexaenoic acid (docosapentanoic acid (DHA) 22, 6n-3). Nutritional manipulation of the membrane content of PUFAs, particularly of the longer chain omega-3 series (LCn3PUFA), has generated great interest due to their enrichment in various immune cell types, as well as their ability to both reduce AA contents of the membrane and antagonize AA metabolism. Several eicosanoid derivates of AA, including prostaglandin E2 and 4-series leukotrienes, have been implicated in promoting sensitization to allergens and increased disease severity, and thus, adequate LCn3PUFA status during both early immunological development and at the time of established immune-antigen interfacing may modify disease risk.

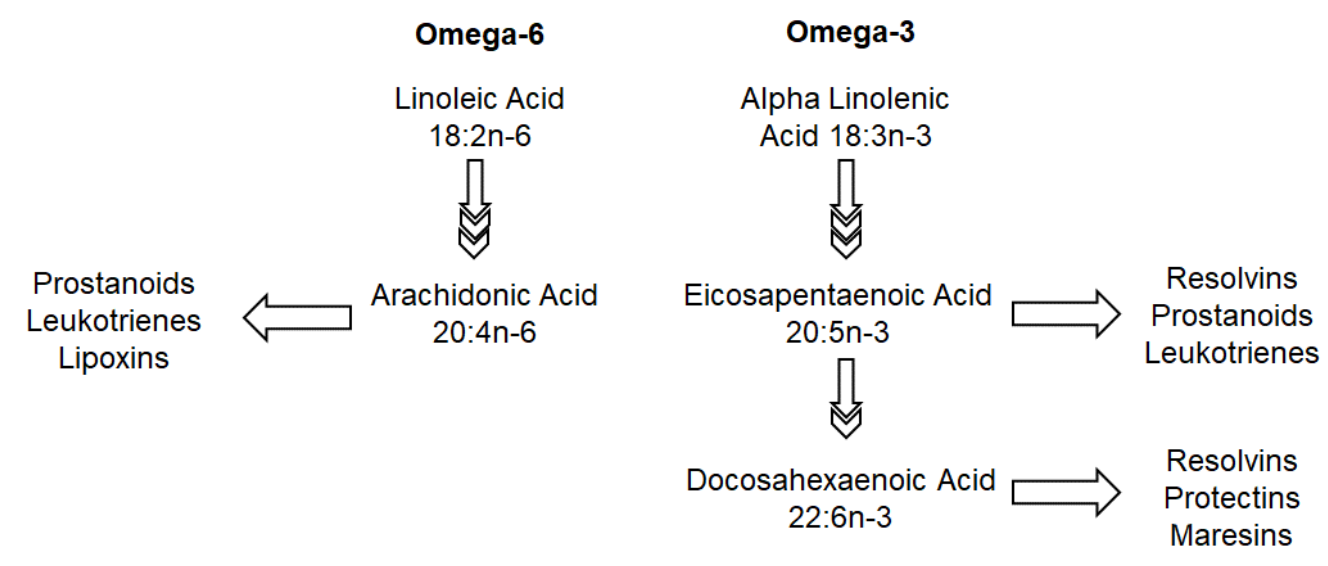

Figure 1. Omega-6 and Omega-3 fatty acid metabolism.

The EAACI position paper suggests that, in patients with the lowest preexisting levels of long-chain polyunsaturated fatty acids (LC-PUFAs), supplementation may be beneficial in allergy prevention, particularly in those with low levels of omega-3 fatty acids [65]. Such protective effects are most commonly seen in pregnant and lactating women, whereby increasing maternal and breast milk LCn3PUFA levels are associated with reduced risk of AD and development of food allergies, although significant heterogeneity in the evidence base exists [65]. Sources of this heterogeneity need further consideration, but likely relate to the dose of LCn3PUFA used in clinical trials, baseline and achieved LCn3PUFA status, the timing of supplementation, common genetic variants throughout fatty acid metabolism and immunity, and microbiome composition [65]. Current recommendations emphasize an individualized approach to nutrition and further, well-designed human studies with challenge-proven food allergy are necessary [66].

LCn3PUFA have received substantial interest for not only their role in prevention of immune-mediated disease, but also their impact on reducing the severity of established disease. In addition to the role of EPA and DHA in antagonizing AA metabolism, they serve as substrates for the production of less potent eicosanoids (from EPA) and specialized pro-resolving mediators (SPMs) [64,67]. SPMs include resolvins (D- and E-series produced from DHA and EPA, respectively), protectins, and maresins (derived from DHA), and appear to act primarily by inhibiting the recruitment and activation of multiple immune cell types, conferring pro-resolving and analgesic properties [68,69]. These novel compounds provide further enthusiasm for omega-3 fatty acids in managing immune-mediated diseases and underlie the enthusiasm for EPA/DHA supplementation in autoimmunity.

Of the available literature base in autoimmune diseases, a substantial body of randomized controlled trials testing the impact of LCn3PUFA, primarily EPA and DHA mixtures, exist for both inflammatory bowel diseases and rheumatoid arthritis. To date, the literature in inflammatory bowel disease has been disappointing. Available systematic reviews and meta-analyses of controlled 
trials [70-74] consistently show that LCn3PUFA supplementation does not prolong states of disease remission in Ulcerative Colitis or Crohn's Disease, and there is high uncertainty due to low quality about the effect of LCn3PUFA in active disease. Notably, supplementation is not without side effects, with patients exhibiting an increased risk of diarrhea and upper gastrointestinal side effects. The complexity of the immunopathology of Ulcerative Colitis and Crohn's Disease, involving impaired mucosal barrier function, varied cell types of the innate and adaptive immune system and their secreted mediators, gut microbial composition and the response to other various luminal factors make it difficult to explain why LCn3PUFAs have likely failed to influence clinical disease. Recent studies in animal models employing the dextran sulphate sodium model of colitis additionally suggest that high-dose LCn3PUFA worsen disease phenotypes when started just prior to dextran-sulphate-sodium provision [75], conflicting with existing evidence from transgenic Fat1 mice [76], capable of synthesizing their own omega-3 fatty acids, that have demonstrated significant protection from colitis. Such data suggest that the degree of tissue omega-3 status saturation, the relative impact on other fatty acid species, and timing of increased omega- 3 status require further investigation to determine any potential efficacy of omega-3 fatty acids in humans with inflammatory bowel disease.

The impact of LCn3PUFA in rheumatoid arthritis is more promising. Supplementation has been shown to reduce leukotriene B4 [77], a chemotactic factor released from neutrophils that is a key driver of inflammatory arthritis [78]. Consistent with this reduction in causal pathophysiological mediators of disease, systematic reviews and meta-analyses of small clinical trials in rheumatoid arthritis consistently identify reduced non-steroidal anti-inflammatory use, improved pain, joint tenderness and improved physical functioning $[79,80]$. Effective doses of LCn3PUFA in shorter term supplementation trials have tended to be in the pharmacological range ( $>2.5 \mathrm{~g} / \mathrm{d}$ EPA + DHA), though self-reported intakes of food sources of omega-3 fatty acids are associated with improved self-reported disease scores [78,81]. Large, confirmatory trials in patients with rheumatoid arthritis are needed for LCn3PUFA status monitoring and supplementation to become standard of care; indeed, the available evidence leaves many questions about the optimal dose, duration, and composition of omega- 3 fatty acids, their effectiveness alongside modern medications (e.g., TNF-alpha inhibitors), and their role in sero-positive vs sero-negative disease states.

\subsection{Fiber}

In line with the role of nutrition on the immune system, we have more a glimpse than a profound understanding of how the microbiome can be beneficially influenced by dietary compounds. However, it is well appreciated that fibers as non-digestible parts of fruits, vegetables and cereals are an important energy source for bacteria that, by fermentation, lead to the production of short-chain fatty acids (SCFA) as essential nutrients for humans. In numerous studies using different fiber interventions, fibers have been attributed to maintain intestinal homeostasis by enhancing epithelial barrier function, inhibiting pathogen-induced cytotoxicity and preventing colonization with pathogenic bacteria.

Despite most studies having been performed in in vivo animal models, there is early proof that fiber intake can also ameliorate pathology in humans in various organs. A high-fiber diet favors microbial diversity and production of SCFA and prevents the fermentation of less favorable substrates such as proteins and amino acids, leading to a reduced risk for colorectal cancer and Crohn's disease $[82,83]$. In addition, SCFA are absorbed and distributed systemically via blood circulation and thereby, may also prevent pathologies outside the gut. Patients suffering from asthma or cystic fibrosis present with a reduced microbial diversity in the gut leading to a shift from SCFA production to lipid, amino acid and carbohydrate metabolism [84,85]. A long-term fiber-rich diet has been shown to improve lung function and to lower the risk for COPD [86,87]. In addition to this microbial gut-lung axis, evidence exists that the gut-brain axis can also be influenced by fibers beneficially. Studies using dietary supplementation with Glucose-oligosaccharides or human milk oligosaccharides indicated a reduction of anxiety scores in irritative bowel syndrome patients and acetate influenced appetite by enhancing the production of regulatory neuropeptides $[88,89]$. Furthermore, people following 
a Mediterranean diet (30 g fiber/day) have a lower risk for type-2 diabetes and patients at risk for cardiovascular disease show lower incidence of events, highlighting the beneficial effects of fibers on metabolic syndrome [90-92]. Mechanistically, high-fiber diets may influence immune-mediated diseases, e.g., by the impact of SCFAs on signaling through G-protein coupled receptors (GPR), namely GRP41, GPR43 and GPR109A [93-95], that are highly expressed on a variety of tissues including myeloid-derived immune cells. Additionally, acetate and butyrate, two common SCFAs, exhibit the capacity to inhibit histone deacetylase activity [95,96], broadly influencing chromatin structure and the epigenetic state of the cell. Further in vivo animal work and human studies are needed to assess the contribution of epigenetic modifications to immune cell function, though a significant body of work suggests that HDAC inhibition in epithelial cells is critical for barrier function and influencing the immune response [97].

This highlights the potential of fibers as an important tool for disease prevention [98]. The challenge in the future will be to integrate fibers into our diets and efforts should be undertaken to educate children (and adults) to at least reach the recommended intake of 25-31 g fiber/day or even higher amounts (Table 2). However, personalized approaches also need to be implemented as one-size does not fit all and, under certain underlying diseases (e.g., inflammatory bowel disease) and prompt increase of dietary fiber content, unwanted side effects of a high-fiber diet such as flatulence, stomachaches, constipation and diarrhea might occur.

Table 2. Institute of Medicine guidance on fat and fiber intake [99].

\begin{tabular}{|c|c|c|c|c|c|c|c|c|}
\hline Calorie Level(s) Assessed & & 1000 & 1200 & 1400,1600 & 1600 & 1800 & 1800 & $2200,2800,3200$ \\
\hline \multicolumn{9}{|l|}{ Macronutrients } \\
\hline Total fat, $\%$ kcal & AMDR & $30-40$ & $25-35$ & $25-35$ & $25-35$ & $25-35$ & $25-35$ & $25-35$ \\
\hline Saturated fat, $\% \mathrm{kcal}$ & DGA & $<10 \%$ & $<10 \%$ & $<10 \%$ & $<10 \%$ & $<10 \%$ & $<10 \%$ & $<10 \%$ \\
\hline Linoleic acid, $g$ & $\mathrm{AI}$ & 7 & 10 & 10 & 10 & 12 & 11 & 16 \\
\hline Linolenic acid, $\mathrm{g}$ & $\mathrm{AI}$ & 0.7 & 0.9 & 0.9 & 1 & 1.2 & 1.1 & 1.6 \\
\hline Fiber & $14 \mathrm{~g} / 1000 \mathrm{kcal}$ & 14 & 16.8 & 19.6 & 22.4 & 25.2 & 25.2 & \\
\hline
\end{tabular}

\section{Future Directions}

The relationship of diet to allergy prevention and autoimmune disease management illustrates the complexity of the questions at hand, in addition to the limitations of the available evidence base. Numerous diet-x-immune-x-microbiome interactions are likely relevant, in addition to the heterogeneity in patient and at-risk population characteristics. Such complexity obscures clear identification of signals for dietary modification, although many bioplausible relationships exist. In addition to well-controlled feeding trials and rigorous prospective cohort studies, below we discuss additional considerations for advancing this field of study in allergy and autoimmune diseases, with relevance to additional immune-mediated pathologies.

\section{Accounting for Dietary Patterns}

Individual nutrient approaches allow for clear tests of hypotheses about their relationship to disease risk and management. However, individual nutrients are consumed in the context of overall dietary patterns and interpretation of results must be appropriately contextualized in this manner. The effect size of individual nutrients is often small and thus, diets differing in multiple nutrients may be of interest to assess their impact on disease outcomes; however, some nutrients target common pathways and it is difficult to know whether multi-nutrient interventions will have additive, interactive, or antagonistic effects on each other. Similar to the trials of the Dietary Approaches to Stop Hypertension (DASH) diet, and DASH-Sodium trials [100,101], trials of whole dietary patterns thought to influence the immune system and disease risk, concomitantly modifying individual nutrients hypothesized 
to strongly influence outcomes of interest, are warranted in the field of nutritional immunology. Further characterization of the total diet and derivation of dietary patterns that appear protective against the development of immune-related diseases may further advance the field and provide the basis for future, rigorous trials and preclinical investigations to identify novel, immunomodulatory dietary components.

\section{The Way Forward}

Nutritional interventions contain the potential to prevent or improve disease. However, until reliable recommendations can be given to physicians and patients, mechanistic studies of nutritional patterns and/or single nutrients on immune function, microbiological and epigenetic changes have to be performed to fully understand the role of nutrition on disease outcomes (Figure 2, Box 1). In addition, studies are needed that comprehensively link all three components together and determine causal mediators of nutrient-induced physiological changes and health outcomes.

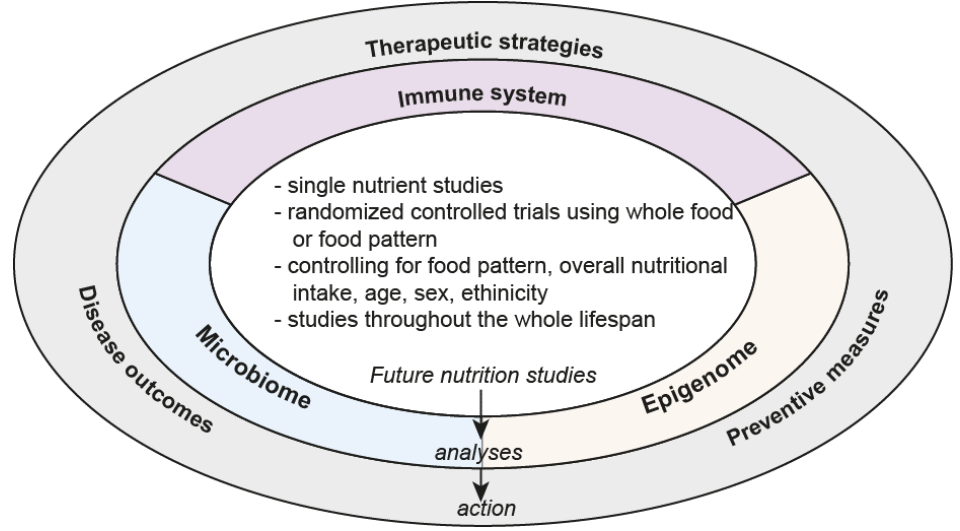

Figure 2. Future direction of nutritional research.

To study these multifactorial exposures requires coordinated interdisciplinary efforts, but performed well, can lead to a global change in the prevention and management of non-communicable diseases. Addressing the current state of the literature and undertaking such interdisciplinary efforts will require a commitment from the broader scientific community to funding well-powered, controlled feeding studies in both preclinical designs and human trials across diverse populations.

Box 1. The way forward in nutrition research.

1. Randomized controlled trials using food patterns/whole diets controlling for environmental factors such as air quality, water content, exposure to sunlight.

2. Single-nutrient studies controlling for other dietary/environmental factors

3. Mechanistic studies focusing on how food impacts on the immune system, microbiome, epigenome and genome and interaction of these components

4. Trials controlling for sex, ethnicity and race

5. Improved tools to measure dietary intake

\section{Conclusions}

Clinicians strive to provide answers to their patients, but there are many unanswered questions related to the role of nutrition on disease prevention [102,103]. Two of the nutrients often studied (but not exclusively studied) in their relation to the immune system are LCn3PUFA and fiber, but much information is required before disease-specific recommendations can be made with high confidence. Perhaps the answer does not lie in single nutrients alone; more focus on randomized controlled 
trials modifying multiple immune-modulating dietary components as part of a broader dietary patterns should be conducted. Until clear answers are found, the nutrition world will continue to, often contentiously, argue for specific dietary recommendations on low-quality evidence. Once we truly know how the enjoyment of eating can be linked with evidence-based medicinal outcomes, we can then focus on effective implementation of such interventions.

Author Contributions: All authors contributed the paper and approved the final version of the paper. C.V. and T.S. wrote the sections relating to allergy. K.C.K. wrote the section relating to omega-3 fatty acids (other than the section on allergies) and revised the sections on future directions. S.E. wrote the section relation to the microbiome (other than the section on allergies). All authors have read and agreed to the published version of the manuscript.

Funding: This research received no external funding.

Conflicts of Interest: C.V. provided educational material or reviewed educational materials for Abbott Laboratories, Danone, and Reckitt Benckiser.

\section{References}

1. Meydani, S.N.; Das, S.K.; Pieper, C.F.; Lewis, M.R.; Klein, S.; Dixit, V.D.; Gupta, A.K.; Villareal, D.T.; Bhapkar, M.; Huang, M.; et al. Long-term moderate calorie restriction inhibits inflammation without impairing cell-mediated immunity: A randomized controlled trial in non-obese humans. Aging 2016, 8, 1416-1431. [CrossRef] [PubMed]

2. Allaire, J.; Couture, P.; Leclerc, M.; Charest, A.; Marin, J.; Lepine, M.C.; Talbot, D.; Tchernof, A.; Lamarche, B. A randomized, crossover, head-to-head comparison of eicosapentaenoic acid and docosahexaenoic acid supplementation to reduce inflammation markers in men and women: The Comparing EPA to DHA (ComparED) Study. Am. J. Clin. Nutr. 2016, 104, 280-287. [CrossRef]

3. Huang, S.C.; Wei, J.C.; Wu, D.J.; Huang, Y.C. Vitamin B(6) supplementation improves pro-inflammatory responses in patients with rheumatoid arthritis. Eur. J. Clin. Nutr. 2010, 64, 1007-1013. [CrossRef] [PubMed]

4. Luukkonen, P.K.; Sadevirta, S.; Zhou, Y.; Kayser, B.; Ali, A.; Ahonen, L.; Lallukka, S.; Pelloux, V.; Gaggini, M.; Jian, C.; et al. Saturated Fat Is More Metabolically Harmful for the Human Liver Than Unsaturated Fat or Simple Sugars. Diabetes Care 2018, 41, 1732-1739. [CrossRef] [PubMed]

5. Ulven, S.M.; Christensen, J.J.; Nygard, O.; Svardal, A.; Leder, L.; Ottestad, I.; Lysne, V.; Laupsa-Borge, J.; Ueland, P.M.; Midttun, O.; et al. Using metabolic profiling and gene expression analyses to explore molecular effects of replacing saturated fat with polyunsaturated fat-a randomized controlled dietary intervention study. Am. J. Clin. Nutr. 2019, 109, 1239-1250. [CrossRef] [PubMed]

6. Jiang, X.; Bar, H.Y.; Yan, J.; Jones, S.; Brannon, P.M.; West, A.A.; Perry, C.A.; Ganti, A.; Pressman, E.; Devapatla, S.; et al. A higher maternal choline intake among third-trimester pregnant women lowers placental and circulating concentrations of the antiangiogenic factor fms-like tyrosine kinase-1 (sFLT1). FASEB J. 2013, 27, 1245-1253. [CrossRef] [PubMed]

7. Estruch, R. Anti-inflammatory effects of the Mediterranean diet: The experience of the PREDIMED study. Proc. Nutr. Soc. 2010, 69, 333-340. [CrossRef]

8. Bedard, A.; Lamarche, B.; Corneau, L.; Dodin, S.; Lemieux, S. Sex differences in the impact of the Mediterranean diet on systemic inflammation. Nutr. J. 2015, 14, 46. [CrossRef]

9. Mestas, J.; Hughes, C.C. Of mice and not men: Differences between murine and human immunology. J. Immunol. 2004, 172, 2731-2738. [CrossRef]

10. Shay, T.; Jojic, V.; Zuk, O.; Rothamel, K.; Puyraimond-Zemmour, D.; Feng, T.; Wakamatsu, E.; Benoist, C.; Koller, D.; Regev, A.; et al. Conservation and divergence in the transcriptional programs of the human and murine immune systems. Proc. Natl. Acad. Sci. USA 2013, 110, 2946-2951. [CrossRef]

11. Writing Group for the TSG; Knip, M.; Akerblom, H.K.; Al Taji, E.; Becker, D.; Bruining, J.; Castano, L.; Danne, T.; de Beaufort, C.; Dosch, H.M.; et al. Effect of Hydrolyzed Infant Formula vs. Conventional Formula on Risk of Type 1 Diabetes: The TRIGR Randomized Clinical Trial. JAMA 2018, 319, 38-48. [CrossRef] [PubMed]

12. Schwingshackl, L.; Hoffmann, G. Diet quality as assessed by the Healthy Eating Index, the Alternate Healthy Eating Index, the Dietary Approaches to Stop Hypertension score, and health outcomes: A systematic review and meta-analysis of cohort studies. J. Acad. Nutr. Diet. 2015, 115, 780-800. [CrossRef] [PubMed] 
13. Schulze, M.B.; Martinez-Gonzalez, M.A.; Fung, T.T.; Lichtenstein, A.H.; Forouhi, N.G. Food based dietary patterns and chronic disease prevention. BMJ 2018, 361, k2396. [CrossRef] [PubMed]

14. Hirata, S.I.; Kunisawa, J. Gut microbiome, metabolome, and allergic diseases. Allergol. Int. 2017, 66, 523-528. [CrossRef]

15. Wesemann, D.R.; Nagler, C.R. The Microbiome, Timing, and Barrier Function in the Context of Allergic Disease. Immunity 2016, 44, 728-738. [CrossRef]

16. Volynets, V.; Louis, S.; Pretz, D.; Lang, L.; Ostaff, M.J.; Wehkamp, J.; Bischoff, S.C. Intestinal Barrier Function and the Gut Microbiome Are Differentially Affected in Mice Fed a Western-Style Diet or Drinking Water Supplemented with Fructose. J. Nutr. 2017, 147, 770-780. [CrossRef]

17. Yatsunenko, T.; Rey, F.E.; Manary, M.J.; Trehan, I.; Dominguez-Bello, M.G.; Contreras, M.; Magris, M.; Hidalgo, G.; Baldassano, R.N.; Anokhin, A.P.; et al. Human gut microbiome viewed across age and geography. Nature 2012, 486, 222-227. [CrossRef]

18. Shen, D.; Liu, C.; Xu, R.; Zhang, F. Human gut microbiota: Dysbiosis and manipulation. Front. Cell. Infect. Microbiol. 2012, 2, 123. [CrossRef]

19. Hildebrandt, M.A.; Hoffmann, C.; Sherrill-Mix, S.A.; Keilbaugh, S.A.; Hamady, M.; Chen, Y.Y.; Knight, R.; Ahima, R.S.; Bushman, F.; Wu, G.D. High-fat diet determines the composition of the murine gut microbiome independently of obesity. Gastroenterology 2009, 137, 1716-1724. [CrossRef]

20. David, L.A.; Maurice, C.F.; Carmody, R.N.; Gootenberg, D.B.; Button, J.E.; Wolfe, B.E.; Ling, A.V.; Devlin, A.S.; Varma, Y.; Fischbach, M.A.; et al. Diet rapidly and reproducibly alters the human gut microbiome. Nature 2014, 505, 559-563. [CrossRef]

21. Venter, C.; Maslin, K.; Dean, T.; Holloway, J.; Silveira, L.; Fleischer, D.; Dean, T.; Arshad, H. Different measures of dietary diversity during infancy and the association with childhood food allergy in a UK birth cohort study. J. Allergy Clin. Immunol. Pract. 2020, 8, 1088-1090.

22. Nwaru, B.I.; Takkinen, H.M.; Kaila, M.; Erkkola, M.; Ahonen, S.; Pekkanen, J.; Simell, O.; Veijola, R.; Ilonen, J.; Hyoty, H.; et al. Food diversity in infancy and the risk of childhood asthma and allergies. J. Allergy Clin. Immunol. 2014, 133, 1084-1091. [CrossRef] [PubMed]

23. Roduit, C.; Frei, R.; Depner, M.; Schaub, B.; Loss, G.; Genuneit, J.; Pfefferle, P.; Hyvarinen, A.; Karvonen, A.M.; Riedler, J.; et al. Increased food diversity in the first year of life is inversely associated with allergic diseases. J. Allergy Clin. Immunol. 2014, 133, 1056-1064. [CrossRef] [PubMed]

24. Claesson, M.J.; Jeffery, I.B.; Conde, S.; Power, S.E.; O'Connor, E.M.; Cusack, S.; Harris, H.M.; Coakley, M.; Lakshminarayanan, B.; O'Sullivan, O.; et al. Gut microbiota composition correlates with diet and health in the elderly. Nature 2012, 488, 178-184. [CrossRef]

25. Roduit, C.; Frei, R.; Ferstl, R.; Loeliger, S.; Westermann, P.; Rhyner, C.; Chassard, C. High levels of butyrate and propionate in early life are associated with protection against atopy. Allergy 2019, 74, 799-809. [CrossRef]

26. Benson, M.J.; Pino-Lagos, K.; Rosemblatt, M.; Noelle, R.J. All-trans retinoic acid mediates enhanced T reg cell growth, differentiation, and gut homing in the face of high levels of co-stimulation. J. Exp. Med. 2007, 204, 1765-1774. [CrossRef]

27. Kinoshita, M.; Kayama, H.; Kusu, T.; Yamaguchi, T.; Kunisawa, J.; Kiyono, H.; Sakaguchi, S.; Takeda, K. Dietary folic acid promotes survival of Foxp3+ regulatory T cells in the colon. J. Immunol. 2012, 189, 2869-2878. [CrossRef]

28. Kishino, S.; Takeuchi, M.; Park, S.B.; Hirata, A.; Kitamura, N.; Kunisawa, J.; Kiyono, H.; Iwamoto, R.; Isobe, Y.; Arita, M.; et al. Polyunsaturated fatty acid saturation by gut lactic acid bacteria affecting host lipid composition. Proc. Natl. Acad. Sci. USA 2013, 110, 17808-17813. [CrossRef]

29. Krause, K.; Metz, M.; Makris, M.; Zuberbier, T.; Maurer, M. The role of interleukin-1 in allergy-related disorders. Curr. Opin. Allergy Clin. Immunol. 2012, 12, 477-484. [CrossRef]

30. Li, K.; Huang, T.; Zheng, J.; Wu, K.; Li, D. Effect of marine-derived n-3 polyunsaturated fatty acids on C-reactive protein, interleukin 6 and tumor necrosis factor alpha: A meta-analysis. PLoS ONE 2014, 9, e88103.

31. Costenbader, K.H.; MacFarlane, L.A.; Lee, I.M.; Buring, J.E.; Mora, S.; Bubes, V.; Kotler, G.; Camargo, C.A., Jr.; Manson, J.E.; Cook, N.R. Effects of One Year of Vitamin D and Marine Omega-3 Fatty Acid Supplementation on Biomarkers of Systemic Inflammation in Older US Adults. Clin. Chem. 2019, 65, 1508-1521. [CrossRef] [PubMed] 
32. Luo, T.; Ji, W.J.; Yuan, F.; Guo, Z.Z.; Li, Y.X.; Dong, Y.; Ma, Y.Q.; Zhou, X.; Li, Y.M. Th17/Treg Imbalance Induced by Dietary Salt Variation Indicates Inflammation of Target Organs in Humans. Sci. Rep. 2016, 6, 26767. [CrossRef] [PubMed]

33. Hernandez, A.L.; Kitz, A.; Wu, C.; Lowther, D.E.; Rodriguez, D.M.; Vudattu, N.; Deng, S.; Herold, K.C.; Kuchroo, V.K.; Kleinewietfeld, M.; et al. Sodium chloride inhibits the suppressive function of FOXP3+ regulatory T cells. J. Clin. Investig. 2015, 125, 4212-4222. [CrossRef] [PubMed]

34. Kleinewietfeld, M.; Manzel, A.; Titze, J.; Kvakan, H.; Yosef, N.; Linker, R.A.; Muller, D.N.; Hafler, D.A. Sodium chloride drives autoimmune disease by the induction of pathogenic TH17 cells. Nature 2013, 496, 518-522. [CrossRef] [PubMed]

35. Wilck, N.; Matus, M.G.; Kearney, S.M.; Olesen, S.W.; Forslund, K.; Bartolomaeus, H.; Haase, S.; Mahler, A.; Balogh, A.; Marko, L.; et al. Salt-responsive gut commensal modulates TH17 axis and disease. Nature 2017, 551, 585-589. [CrossRef]

36. Hall, W.L.; Vafeiadou, K.; Hallund, J.; Bugel, S.; Koebnick, C.; Reimann, M.; Ferrari, M.; Branca, F.; Talbot, D.; Dadd, T.; et al. Soy-isoflavone-enriched foods and inflammatory biomarkers of cardiovascular disease risk in postmenopausal women: Interactions with genotype and equol production. Am. J. Clin. Nutr. 2005, 82, 1260-1268. [CrossRef]

37. Kepert, I.; Fonseca, J.; Muller, C.; Milger, K.; Hochwind, K.; Kostric, M.; Fedoseeva, M.; Ohnmacht, C.; Dehmel, S.; Nathan, P.; et al. D-tryptophan from probiotic bacteria influences the gut microbiome and allergic airway disease. J. Allergy Clin. Immunol. 2017, 139, 1525-1535. [CrossRef]

38. Turner, J.R. Intestinal mucosal barrier function in health and disease. Nat. Rev. Immunol. 2009, 9, 799-809. [CrossRef]

39. Raman, K.G.; Sappington, P.L.; Yang, R.; Levy, R.M.; Prince, J.M.; Liu, S.; Watkins, S.K.; Schmidt, A.M.; Billiar, T.R.; Fink, M.P. The role of RAGE in the pathogenesis of intestinal barrier dysfunction after hemorrhagic shock. Am. J. Physiol. Gastrointest. Liver Physiol. 2006, 291, G556-G565. [CrossRef]

40. Uribarri, J.; Woodruff, S.; Goodman, S.; Cai, W.; Chen, X.; Pyzik, R.; Yong, A.; Striker, G.E.; Vlassara, H. Advanced glycation end products in foods and a practical guide to their reduction in the diet. J. Am. Dietelic Assoc. 2010, 110, 911-916. [CrossRef]

41. Seiquer, I.; Rubio, L.A.; Peinado, M.J.; Delgado-Andrade, C.; Navarro, M.P. Maillard reaction products modulate gut microbiota composition in adolescents. Mol. Nutr. Food Res. 2014, 58, 1552-1560. [CrossRef] [PubMed]

42. DeChristopher, L.R.; Uribarri, J.; Tucker, K.L. Intakes of apple juice, fruit drinks and soda are associated with prevalent asthma in US children aged 2-9 years. Public Health Nutr. 2016, 19, 123-130. [CrossRef] [PubMed]

43. DeChristopher, L.R.; Uribarri, J.; Tucker, K.L. Intake of high-fructose corn syrup sweetened soft drinks, fruit drinks and apple juice is associated with prevalent arthritis in US adults, aged 20-30 years. Nutr. Diabetes 2016, 6, e199. [CrossRef] [PubMed]

44. DeChristopher, L.R.; Uribarri, J.; Tucker, K.L. Intake of high fructose corn syrup sweetened soft drinks is associated with prevalent chronic bronchitis in U.S. Adults, ages 20-55 y. Nutr. J. 2015, 14, 107. [CrossRef] [PubMed]

45. DeChristopher, L.R.; Uribarri, J.; Tucker, K.L. The link between soda intake and asthma: Science points to the high-fructose corn syrup, not the preservatives: A commentary. Nutr. Diabetes 2016, 6, e234. [CrossRef]

46. Kellow, N.J.; Coughlan, M.T.; Savige, G.S.; Reid, C.M. Effect of dietary prebiotic supplementation on advanced glycation, insulin resistance and inflammatory biomarkers in adults with pre-diabetes: A study protocol for a double-blind placebo-controlled randomised crossover clinical trial. BMC Endocr. Disord. 2014, 14, 55. [CrossRef]

47. Tan, J.; McKenzie, C.; Vuillermin, P.J.; Goverse, G.; Vinuesa, C.G.; Mebius, R.E.; Macia, L.; Mackay, C.R. Dietary Fiber and Bacterial SCFA Enhance Oral Tolerance and Protect against Food Allergy through Diverse Cellular Pathways. Cell Rep. 2016, 15, 2809-2824. [CrossRef]

48. Thorburn, A.N.; McKenzie, C.I.; Shen, S.; Stanley, D.; Macia, L.; Mason, L.J.; Roberts, L.K.; Wong, C.H.; Shim, R.; Robert, R.; et al. Evidence that asthma is a developmental origin disease influenced by maternal diet and bacterial metabolites. Nat. Commun. 2015, 6, 7320. [CrossRef] [PubMed]

49. Fernandez-Navarro, T.; Salazar, N.; Gutierrez-Diaz, I.; de Los Reyes-Gavilan, C.G.; Gueimonde, M.; Gonzalez, S. Different Intestinal Microbial Profile in Over-Weight and Obese Subjects Consuming a Diet with Low Content of Fiber and Antioxidants. Nutrients 2017, 9, 551. [CrossRef] 
50. Gutierrez-Diaz, I.; Fernandez-Navarro, T.; Salazar, N.; Bartolome, B.; Moreno-Arribas, M.V.; de Andres-Galiana, E.J.; Fernandez-Martinez, J.L.; de Los Reyes-Gavilan, C.G.; Gueimonde, M.; Gonzalez, S. Adherence to a Mediterranean Diet Influences the Fecal Metabolic Profile of Microbial-Derived Phenolics in a Spanish Cohort of Middle-Age and Older People. J. Agric. Food Chem. 2017, 65, 586-595. [CrossRef]

51. Chassaing, B.; Koren, O.; Goodrich, J.K.; Poole, A.C.; Srinivasan, S.; Ley, R.E.; Gewirtz, A.T. Dietary emulsifiers impact the murine gut microbiota promoting colitis and metabolic syndrome. Nature 2015, 519, 92-96. [CrossRef] [PubMed]

52. Lang, J.M.; Eisen, J.A.; Zivkovic, A.M. The microbes we eat: Abundance and taxonomy of microbes consumed in a day's worth of meals for three diet types. Peer] 2014, 2, e659. [CrossRef] [PubMed]

53. Venter, C.; Maslin, K. The Future of Infant and Young Children's Food: Food Supply/Manufacturing and Human Health Challenges in the 21st Century. In Preventive Aspects of Early Nutrition; Karger Publishers: Basel, Switzerland, 2016; Volume 85, pp. 19-27.

54. Zota, A.R.; Phillips, C.A.; Mitro, S.D. Recent Fast Food Consumption and Bisphenol A and Phthalates Exposures among the U.S. Population in NHANES, 2003-2010. Environ. Health Perspect. 2016, 124, 1521-1528. [CrossRef]

55. Hu, J.; Raikhel, V.; Gopalakrishnan, K.; Fernandez-Hernandez, H.; Lambertini, L.; Manservisi, F.; Falcioni, L.; Bua, L.; Belpoggi, F.; Teitelbaum, S.L.; et al. Effect of postnatal low-dose exposure to environmental chemicals on the gut microbiome in a rodent model. Microbiome 2016, 4, 26. [CrossRef] [PubMed]

56. Agache, I.; Akdis, C.A. Precision medicine and phenotypes, endotypes, genotypes, regiotypes, and theratypes of allergic diseases. J. Clin. Investig. 2019, 130, 1493-1503. [CrossRef] [PubMed]

57. Boyce, J.A.; Assa'a, A.; Burks, A.W.; Jones, S.M.; Sampson, H.A.; Wood, R.A.; Plaut, M.; Cooper, S.F.; Fenton, M.J.; Arshad, S.H.; et al. Guidelines for the diagnosis and management of food allergy in the United States: Summary of the NIAID-Sponsored Expert Panel Report. Nutrition 2011, 27, 253-267. [CrossRef]

58. Food Allergies: Global Burden, Causes, Treatment, Prevention and Public Policy. Available online: http://wwwnationalacademiesorg/hmd/Activities/Nutrition/FoodAllergiesaspx (accessed on 16 March 2020).

59. Immunology EAoAaC: Global Atlas of Allergy. Available online: http:/wwweaaciorg/GlobalAtlas/ GlobalAtlasAllergypdf (accessed on 16 March 2020).

60. Sicherer, S.H.; Sampson, H.A. Food allergy: A review and update on epidemiology, pathogenesis, diagnosis, prevention, and management. J. Allergy Clin. Immunol. 2018, 141, 41-58. [CrossRef]

61. Akdis, M.; Aab, A.; Altunbulakli, C.; Azkur, K.; Costa, R.A.; Crameri, R.; Duan, S.; Eiwegger, T.; Eljaszewicz, A.; Ferstl, R.; et al. Interleukins (from IL-1 to IL-38), interferons, transforming growth factor beta, and TNF-alpha: Receptors, functions, and roles in diseases. J. Allergy Clin. Immunol. 2016, 138, 984-1010. [CrossRef]

62. Venter, C.; Greenhawt, M.; Meyer, R.W.; Agostoni, C.; Reese, I.; du Toit, G.; Feeney, M.; Maslin, K.; Nwaru, B.I.; Roduit, C.; et al. EAACI position paper on diet diversity in pregnancy, infancy and childhood: Novel concepts and implications for studies in allergy and asthma. Allergy 2019, 75, 497-523. [CrossRef]

63. Schett, G.; Neurath, M.F. Resolution of chronic inflammatory disease: Universal and tissue-specific concepts. Nat. Commun. 2018, 9, 3261. [CrossRef]

64. Marion-Letellier, R.; Savoye, G.; Ghosh, S. Polyunsaturated fatty acids and inflammation. IUBMB Life 2015, 67, 659-667. [CrossRef] [PubMed]

65. Venter, C.; Meyer, R.W.; Nwaru, B.I.; Roduit, C.; Untersmayr, E.; Adel-Patient, K.; Agache, I.; Agostoni, C.; Akdis, C.A.; Bischoff, S.; et al. EAACI position paper: Influence of dietary fatty acids on asthma, food allergy, and atopic dermatitis. Allergy 2019, 74, 1429-1444. [CrossRef]

66. D'Auria, E.; Abrahams, M.; Zuccotti, G.V.; Venter, C. Personalized Nutrition Approach in Food Allergy: Is It Prime Time Yet? Nutrients 2019, 11, 359. [CrossRef] [PubMed]

67. Calder, P.C. Omega-3 fatty acids and inflammatory processes: From molecules to man. Biochem. Soc. Trans. 2017, 45, 1105-1115. [CrossRef] [PubMed]

68. Basil, M.C.; Levy, B.D. Specialized pro-resolving mediators: Endogenous regulators of infection and inflammation. Nat. Rev. Immunol. 2016, 16, 51-67. [CrossRef]

69. Souza, P.R.; Marques, R.M.; Gomez, E.A.; Colas, R.A.; De Matteis, R.; Zak, A.; Patel, M.; Collier, D.J.; Dalli, J. Enriched Marine Oil Supplements Increase Peripheral Blood Specialized Pro-Resolving Mediators Concentrations and Reprogram Host Immune Responses: A Randomized Double-Blind Placebo-Controlled Study. Circ. Res. 2019, 126, 75-90. [CrossRef] 
70. MacLean, C.H.; Mojica, W.A.; Newberry, S.J.; Pencharz, J.; Garland, R.H.; Tu, W.; Hilton, L.G.; Gralnek, I.M.; Rhodes, S.; Khanna, P.; et al. Systematic review of the effects of $\mathrm{n}-3$ fatty acids in inflammatory bowel disease. Am. J. Clin. Nutr. 2005, 82, 611-619. [CrossRef]

71. Turner, D.; Shah, P.S.; Steinhart, A.H.; Zlotkin, S.; Griffiths, A.M. Maintenance of remission in inflammatory bowel disease using omega-3 fatty acids (fish oil): A systematic review and meta-analyses. Inflamm. Bowel Dis. 2011, 17, 336-345. [CrossRef]

72. Turner, D.; Steinhart, A.H.; Griffiths, A.M. Omega 3 fatty acids (fish oil) for maintenance of remission in ulcerative colitis. Cochrane Database Syst. Rev. 2007, 3, CD006443.

73. Lev-Tzion, R.; Griffiths, A.M.; Leder, O.; Turner, D. Omega 3 fatty acids (fish oil) for maintenance of remission in Crohn's disease. Cochrane Database Syst. Rev. 2014. [CrossRef]

74. Cabré, E.; Mañosa, M.; Gassull, M.A. Omega-3 fatty acids and inflammatory bowel diseases-A systematic review. Br. J. Nutr. 2012, 107, S240-S252. [CrossRef] [PubMed]

75. Matsunaga, H.; Hokari, R.; Kurihara, C.; Okada, Y.; Takebayashi, K.; Okudaira, K.; Watanabe, C.; Komoto, S.; Nakamura, M.; Tsuzuki, Y.; et al. Omega-3 fatty acids exacerbate DSS-induced colitis through decreased adiponectin in colonic subepithelial myofibroblasts. Inflamm. Bowel Dis. 2008, 14, 1348-1357. [CrossRef] [PubMed]

76. Hudert, C.A.; Weylandt, K.H.; Lu, Y.; Wang, J.; Hong, S.; Dignass, A.; Serhan, C.N.; Kang, J.X. Transgenic mice rich in endogenous omega-3 fatty acids are protected from colitis. Proc. Natl. Acad. Sci. USA 2006, 103, 11276-11281. [CrossRef] [PubMed]

77. Kremer, J.M.; Lawrence, D.A.; Jubiz, W.; DiGiacomo, R.; Rynes, R.; Bartholomew, L.E.; Sherman, M. Dietary fish oil and olive oil supplementation in patients with rheumatoid arthritis. Clinical and immunologic effects. Arthritis Rheumatol. 1990, 33, 810-820. [CrossRef]

78. Chen, M.; Lam, B.K.; Kanaoka, Y.; Nigrovic, P.A.; Audoly, L.P.; Frank Austen, K.; Lee, D.M. Neutrophil-derived leukotriene B4 is required for inflammatory arthritis. J. Exp. Med. 2006, 203, 837-842. [CrossRef]

79. Lee, Y.-H.; Bae, S.-C.; Song, G.-G. Omega-3 polyunsaturated fatty acids and the treatment of rheumatoid arthritis: A meta-analysis. Arch. Med. Res. 2012, 43, 356-362. [CrossRef]

80. Kagalwalla, A.F.; Akhtar, N.; Woodruff, S.A.; Rea, B.A.; Masterson, J.C.; Mukkada, V.; Parashette, K.R.; Du, J.; Fillon, S.; Protheroe, C.A.; et al. Eosinophilic esophagitis: Epithelial mesenchymal transition contributes to esophageal remodeling and reverses with treatment. J. Allergy Clin. Immunol. 2012, 129, 1387-1396. [CrossRef]

81. Beyer, K.; Lie, S.A.; Kjellevold, M.; Dahl, L.; Brun, J.G.; Bolstad, A.I. Marine $\omega-3$, vitamin D levels, disease outcome and periodontal status in rheumatoid arthritis outpatients. Nutrition 2018, 55, 116-124. [CrossRef]

82. Ananthakrishnan, A.N.; Khalili, H.; Konijeti, G.G.; Higuchi, L.M.; de Silva, P.; Korzenik, J.R.; Fuchs, C.S.; Willett, W.C.; Richter, J.M.; Chan, A.T. A prospective study of long-term intake of dietary fiber and risk of Crohn's disease and ulcerative colitis. Gastroenterology 2013, 145, 970-977. [CrossRef]

83. Aune, D.; Keum, N.; Giovannucci, E.; Fadnes, L.T.; Boffetta, P.; Greenwood, D.C.; Tonstad, S.; Vatten, L.J.; Riboli, E.; Norat, T. Whole grain consumption and risk of cardiovascular disease, cancer, and all cause and cause specific mortality: Systematic review and dose-response meta-analysis of prospective studies. BMJ 2016, 353, i2716. [CrossRef]

84. Vernocchi, P.; Del Chierico, F.; Russo, A.; Majo, F.; Rossitto, M.; Valerio, M.; Casadei, L.; La Storia, A.; De Filippis, F.; Rizzo, C.; et al. Gut microbiota signatures in cystic fibrosis: Loss of host CFTR function drives the microbiota enterophenotype. PLOS ONE 2018, 13, e0208171. [CrossRef] [PubMed]

85. Wang, Q.; Li, F.; Liang, B.; Liang, Y.; Chen, S.; Mo, X.; Ju, Y.; Zhao, H.; Jia, H.; Spector, T.D.; et al. A metagenome-wide association study of gut microbiota in asthma in UK adults. BMC Microbiol. 2018, $18,114$. [CrossRef] [PubMed]

86. Keranis, E.; Makris, D.; Rodopoulou, P.; Martinou, H.; Papamakarios, G.; Daniil, Z.; Zintzaras, E.; Gourgoulianis, K.I. Impact of dietary shift to higher-antioxidant foods in COPD: A randomised trial. Eur. Respir. J. 2010, 36, 774-780. [CrossRef]

87. Szmidt, M.K.; Kaluza, J.; Harris, H.R.; Linden, A.; Wolk, A. Long-term dietary fiber intake and risk of chronic obstructive pulmonary disease: A prospective cohort study of women. Eur. J. Nutr. 2019. [CrossRef]

88. Tarr, A.J.; Galley, J.D.; Fisher, S.E.; Chichlowski, M.; Berg, B.M.; Bailey, M.T. The prebiotics 3'Sialyllactose and 6'Sialyllactose diminish stressor-induced anxiety-like behavior and colonic microbiota alterations: Evidence for effects on the gut-brain axis. Brain Behav. Immun. 2015, 50, 166-177. [CrossRef] [PubMed] 
89. Silk, D.B.; Davis, A.; Vulevic, J.; Tzortzis, G.; Gibson, G.R. Clinical trial: The effects of a trans-galactooligosaccharide prebiotic on faecal microbiota and symptoms in irritable bowel syndrome. Aliment. Pharmacol. Ther. 2009, 29, 508-518. [CrossRef] [PubMed]

90. Estruch, R.; Ros, E.; Salas-Salvado, J.; Covas, M.I.; Corella, D.; Aros, F.; Gomez-Gracia, E.; Ruiz-Gutierrez, V.; Fiol, M.; Lapetra, J.; et al. Primary prevention of cardiovascular disease with a Mediterranean diet. N. Engl. J. Med. 2013, 368, 1279-1290. [CrossRef] [PubMed]

91. Jones, J.L.; Fernandez, M.L.; McIntosh, M.S.; Najm, W.; Calle, M.C.; Kalynych, C.; Vukich, C.; Barona, J.; Ackermann, D.; Kim, J.E.; et al. A Mediterranean-style low-glycemic-load diet improves variables of metabolic syndrome in women, and addition of a phytochemical-rich medical food enhances benefits on lipoprotein metabolism. J. Clin. Lipidol. 2011, 5, 188-196. [CrossRef]

92. Del Chierico, F.; Vernocchi, P.; Dallapiccola, B.; Putignani, L. Mediterranean diet and health: Food effects on gut microbiota and disease control. Int. J. Mol. Sci. 2014, 15, 11678-11699. [CrossRef]

93. Brown, A.J.; Goldsworthy, S.M.; Barnes, A.A.; Eilert, M.M.; Tcheang, L.; Daniels, D.; Pike, N.B. The Orphan G protein-coupled receptors GPR41 and GPR43 are activated by propionate and other short chain carboxylic acids. J. Biol. Chem. 2003, 278, 11312-11319. [CrossRef]

94. Poul, E.L.; Loison, C.; Struyf, S.; Springael, J.Y.; Lannoy, V.; Decobecq, M.E.; Parmentier, M. MECHANISMS OF SIGNAL TRANSDUCTION-Functional Characterization of Human Receptors for Short Chain Fatty Acids and Their Role in Polymorphonuclear Cell Activation. J. Biol. Chem. 2003, 278, 25481-25489. [CrossRef] [PubMed]

95. Bolduc, J.F.; Hany, L.; Barat, C.; Ouellet, M.; Tremblay, M.J. Epigenetic metabolite acetate inhibits class I/II histone deacetylases, promotes histone acetylation, and increases HIV-1 integration in CD4+ T cells. J. Virol. 2017, 91, e01943-16. [CrossRef] [PubMed]

96. Davie, J.R. Inhibition of histone deacetylase activity by butyrate. J. Nutr. 2003, 133, 2485S-2493S. [CrossRef] [PubMed]

97. Zheng, L.; Kelly, C.J.; Battista, K.D.; Schaefer, R.; Lanis, J.M.; Alexeev, E.E.; Colgan, S.P. Microbial-derived butyrate promotes epithelial barrier function through IL-10 receptor-dependent repression of claudin-2. J. Immunol. 2017, 199, 2976-2984. [CrossRef] [PubMed]

98. O'Keefe, S.J.; Li, J.V.; Lahti, L.; Ou, J.; Carbonero, F.; Mohammed, K.; Posma, J.M.; Kinross, J.; Wahl, E.; Ruder, E.; et al. Fat, fibre and cancer risk in African Americans and rural Africans. Nat. Commun. 2015, 6, 6342. [CrossRef]

99. Lupton, J.R.; Brooks, J.A.; Butte, N.F.; Caballero, B.; Flatt, J.P.; Fried, S.K. Dietary Reference Intakes for Energy, Carbohydrate, Fiber, Fat, Fatty Acids, Cholesterol, Protein, and Amino Acids; National Academy Press: Washington, DC, USA, 2002; Volume 5, pp. 589-768.

100. Appel, L.J.; Moore, T.J.; Obarzanek, E.; Vollmer, W.M.; Svetkey, L.P.; Sacks, F.M.; Bray, G.A.; Vogt, T.M.; Cutler, J.A.; Windhauser, M.M.; et al. A clinical trial of the effects of dietary patterns on blood pressure. DASH Collaborative Research Group. N. Engl. J. Med. 1997, 336, 1117-1124. [CrossRef]

101. Sacks, F.M. DASH-Sodium Collaborative Research Group: Effects on blood pressure of reduced dietary sodium and the Dietary Approaches to Stop Hypertension (DASH) diet. N. Engl. J. Med. 2001, 344, 3-10. [CrossRef]

102. Fleischer, D.M.; Spergel, J.M.; Assa'ad, A.H.; Pongracic, J.A. Primary prevention of allergic disease through nutritional interventions. J. Allergy Clin. Immunol. Pract. 2013, 1, 29-36. [CrossRef]

103. Muraro, A.; Halken, S.; Arshad, S.H.; Beyer, K.; Dubois, A.E.; Du Toit, G.; Eigenmann, P.A.; Grimshaw, K.E.; Hoest, A.; Lack, G.; et al. EAACI food allergy and anaphylaxis guidelines. Primary prevention of food allergy. Allergy 2014, 69, 590-601. [CrossRef]

(C) 2020 by the authors. Licensee MDPI, Basel, Switzerland. This article is an open access article distributed under the terms and conditions of the Creative Commons Attribution (CC BY) license (http://creativecommons.org/licenses/by/4.0/). 